\title{
CONTROL STRUCTURE AND UNION FUNCTIONS ${ }^{1}$
}

\author{
ARNOLD S. TANNENBAUM
}

\begin{abstract}
American unions provide an especially fertile field for the exploration and testing of theoretical notions concerning control structure in organizations because of their wide variation in structure. The level of democratic control in a local appears to be related to the members' interest in broad and general goals for their union. Little ground is found for the hypothesis that militant union-management conflict is related to democracy within the local. Rather, union-management conflict affects the total amount of control exercised in the union. The amount of control exercised within a union depends on a number of interrelated causes and effects, including the power of the union, the extent of inter- as well as intra-organizational conflict, and membership loyalty, conformity, and participation.
\end{abstract}

\section{INTRODUCTION}

The importance of control in organizations has led to the development of a number of hypotheses relating it to other aspects of functioning. Relationships have been suggested, for example, between the goals of a union and the form which control will take within it. The "business union," devoted primarily to the enhancement of wages and other specific benefits from management, is predicted to develop strong leadership and an autocratic government. ${ }^{2} \mathrm{~A}$ union's commitment to large social goals, on the other hand, is often considered to be associated with internal democratic procedures. ${ }^{3}$ The relationship between union-management conflict and control has also been the subject of some thought and speculation. Militant conflict with management is said to contribute to membership interest and the main-

${ }^{1}$ The material presented here is adapted in part from a larger report written by the present author in collaboration with Robert L. Kahn and subsidized by the Rockefeller Foundation. The larger study of which this is a part is one of a continuing series on organizational functioning conducted by the staff of the Human Relations Program of the Survey Research Center. I would like to thank Erving Goffman and Joan Lohmann for their contributions to the design and execution of this study, as well as Elizabeth Douvan, Basil Georgopoulos, and Ernest Lilienstein for their helpful comments concerning this paper.

2 R. F. Hoxie, Trade Unionism in the United States (2d ed.; New York: D. Appleton \& Co., 1923), p. 46.

${ }^{3}$ Irving Howe and B. J. Widick, The UAW and Walter Reuther (New York: Random House, 1949), p. 244. tenance of democracy within the union. ${ }^{4} \mathrm{~A}$ related view suggests that unions may be led into undemocratic procedures in an effort to achieve a harmonious relationship with management. Autocratic control is seen as a correlate of "union responsibility." These hypotheses are consistent with the general notion that the form or structure of a union is related to its functions or goals. Furthermore, they imply that the relationship goes one way; the functions determine the structure.

Social psychologists have been interested in control from another point of view: as an independent variable. Interest in the effects of control is reflected in a number of studies from the early research in laboratory groups to the more recent experimental studies in large organizations. Control has been shown to have implications for group cohesiveness, morale, and productivity; ${ }^{6}$ it seems of importance as both a cause and an effect.

${ }^{4}$ Ibid., p. 259.

${ }^{5}$ Seymour Martin Lipset, "The Political Process in Trade Unions: A Theoretical Statement" in Freedom and Control in Modern Society, ed. Morroe Berger, Theodore Abel, and Charles H. Page (New York: D. Van Nostrand Co., Inc., 1954), pp. 82-124.

${ }^{6}$ See, e.g., Kurt Lewin, Ronald Lippitt, and Ralph K. White, "Patterns of Aggressive Behavior in Experimentally Created 'Social Climates," Journal of Social Psychology, X (May, 1939), 5-40; James C. Worthy, "Factors Influencing Employee Morale," Harvard Business Review, XXVIII (January, 1950), 61-73; and Nancy Morse and Everett Reimer, "The Experimental Change of a Major Organizational Variable," Journal of Abnormal and Social Psychology, Vol. LIII (January, 1956). 
The study of control in unions is especially fruitful because of the great variety of practices encountered among the local and international unions in America. One can easily point to unions which exemplify democratic or, if one wishes, autocratic procedures. This great diversity of structural form offers a field for unlimited exploration and comparison. It also poses a serious problem, that of developing descriptive techniques which are capable of capturing some of the essential qualities of union organizations and which at the same time are amenable to standardization and replication.

We have attempted to meet this problem by developing a method of description which is both quantitative and conceptually meaningful. We have called it the "control graph." This scheme characterizes the control structure of an organization in terms of two axes. ${ }^{7}$ The horizontal axis is based on a universal characteristic of formal organizations: the system of hierarchically defined ranks. This axis is designed to represent the various hierarchical levels, from low to high, in the organization. In many local unions, for example, the rank and file would be placed at the low end of this axis, and the president would be placed at the high end, with other officer groups (e.g., the executive board and the bargaining committee) at intervening levels. The vertical axis of the graph represents the amount of control over the organization's policies and actions that is exercised by each of the hierarchical levels. For example, a given level, conceivably, could have very little control in determining the policies and actions of the organization. This might be true of the rank and file in some locals or of the president in others. On the other hand, certain levels might be extremely influential in controlling the affairs of the organization. Again, this might be true of the rank and file, the president, or

${ }^{7} \mathrm{~A}$ more detailed discussion of the control graph as a descriptive technique is presented in an article by Arnold S. Tannenbaum and Robert L. Kahn, "Organizational Control Structure: A General Descriptive Technique as Applied to Four Local Unions," Human Relations (in press). any combination of hierarchical levels. One can see that varying shapes of curve might be generated from these axes, depending on how much control is exercised by each of the hierarchical groups. Four simple prototypes will serve to illustrate the numerous possibilities. These are a few ideal types but by no means the most important theoretically. The graphs as a descriptive technique subsume them all while accounting at the same time for the many variations from these extremes.

1. The democratic model. - This is a curve which rises (i.e., control increases) as one goes down the hierarchy. Groups at lower levels in the hierarchy (such as the rank and file) have more power than groups at higher levels (such as the executive board or the president).

2. The autocratic or oligarchic model.This is a curve which falls (i.e., control decreases) as one goes down the hierarchy.

3. The laissez faire or anarchic model.This is a curve which remains low (i.e., control is low) for all hierarchical levels. No one exercises much control.

4. The polyarchic model.-This is a curve which remains high (i.e., control is high) for all hierarchical levels. All hierarchical groups have important influence in this type of organization.

The foregoing examples help illustrate the importance of two distinct aspects of control in organizations: the distribution of control, i.e., who or what hierarchically defined groups exercise control over the affairs of the organization, and the total amount of control, i.e., how much control is exercised within the organization, from all sources. The first is represented by the shape of the curve, the second by its average height. The one emphasizes the relative power of individuals and groups within the organization, while the other considers its absolute amount. Discussion of control in organizations has more often recognized the former. However, an understanding of control in unions requires an accounting not only of where control resides but of how much it all amounts to. Unions vary much more than do their indus- 
trial counterparts as to both these dimensions. Furthermore, locals which have the same distribution of control may differ markedly in the total amount of control. Similarly, in unions with the same total amount of control, the control may be distributed in quite different ways.

Several hypotheses are discussed later relating these dimensions of control of membership participation, to the ideology of the union, and to the extent to which the union engages in militant conflict with management. An organizational syndrome is suggested which relates control in the union to a larger pattern of variables, including organizational power, inter- and intraorganizational conflict, participation, loyalty, and conformity. While the limited sample of locals does not permit a definitive test of any of the hypotheses, the data are sufficiently suggestive to justify reporting.

\section{SAMPLE}

This article is based on a study of four local unions, all of the industrial type. They are located in Michigan and include between 350 and 850 members. None of the officers is employed full time by the union. Since the study was initiated as an investigation of the factors affecting membership participation, locals were chosen which differ on this variable. Two locals, one high and one low in participation, are in each of two internationals. Differences in participation among the locals as judged by international officers were found to agree with our own measures, which include measures of meeting attendance (both regular and special), member activities at meetings (such as raising and seconding motions, asking questions, etc.), work on committees, and voting in union elections. The locals are assigned fictitious names and, in the order of their level of membership participation, are National, Sergeant, Ensign, and Walker. Sergeant is the largest of the locals, while Ensign is the smallest. The major findings reported here were obtained through paper-and-pencil questionnaires administered to a representative sample of about 150 members in each local. The rate of questionnaire returns averaged over 90 per cent.

\section{CONTROL IN THE FOUR LOCALS}

What picture do the control graphs present of the four locals? Four hierarchical levels were chosen to represent the possible loci of control within each of the locals. The horizontal axis was constructed by employing these hierarchical levels in the following order: (1) the president, (2) the executive board, (3) the plant bargaining committee, and (4) the rank-and-file membership. The amount of control exercised by each of these levels was ascertained through a series of parallel questions. In determining the amount of control exercised by the president, for example, the following question was employed: "In general, how much do you think the president has to say about how things are decided in this local?" Answers were checked on a five-point scale from 1, "He has no say at all," to 5 , "He has a great deal of say." This question was repeated for the executive board, the plant bargaining committee, and the rank-and-file membership. ${ }^{8}$

Figure 1 presents the control curves based on the mean responses to these questions in each of the locals. Three of the curves approximate the prototypes discussed previously. National resembles the democratic model most closely, while Sergeant and Walker approach the polyarchic and laissez faire models, respectively. Ensign does not conform closely to any of the previously discussed prototypes, although the general slope of this curve is positive, with the membership having a relatively high level of control. ${ }^{9}$

${ }^{8}$ The ratings receive some support from observations of the locals as well as from statements of international officers. Further validation of the control graphs as a descriptive technique comes from their recent application in a study of industrial organizations. The curves found in these organizations differ markedly from those in the locals of the present study and, as expected, tend much more in the oligarchic direction.

${ }^{9}$ Statistical tests were performed to determine the significance of the differences in control between the various levels in each local. For example, in 
Walker and Sergeant, both characterized by relatively flat curves, represent locals differing sharply in their total amounts of control. As we shall see, this difference helps explain a number of other variations. On the other hand, while National and Sergeant are

National, where the curve is steep, the membership has a significantly greater amount of control than each of the other groups; in Walker, where the curve is flat, none of the differences is significant (see Tannenbaum and Kahn, op. cit.). similar in total amount of control, the sources of power differ. In National the rank and file is the single most powerful group. In Sergeant the bargaining committee ranks above the membership (although this difference is not statistically significant), and the other levels follow close behind. When acting as a concerted group, the officers in Sergeant are extremely influential and can seriously challenge the members on many issues. This is unlikely in National.

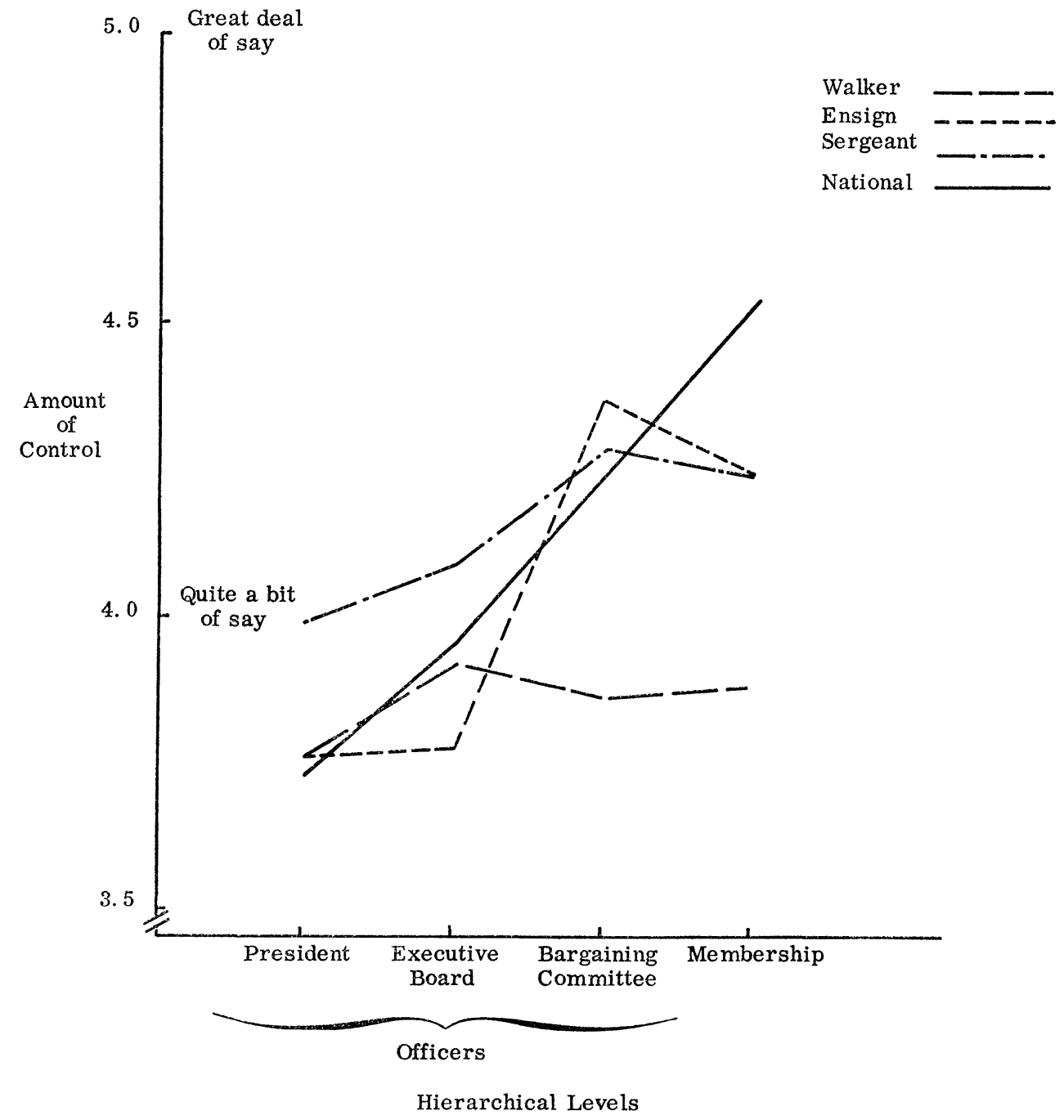

Fig. 1.-Control curves of four union locals based on mean scores of ratings on how much say various persons and groups have in how things are decided in the local. The means are based on $N$ 's of about 150 in each local. 
In discussing some of the hypotheses suggested in the literature, we shall assume that the distribution of control, as represented in the control graph, provides an index of "democratic control." National is the most democratic local of the four, having a curve with the steepest average slope. The rank and file exercises more control in it than in any of the other locals. Ensign is second, having the next most positively sloped curve. The control exercised by its membership ranks second to that in National. Sergeant follows, having a less positively sloped curve. The amount of control exercised by the membership in this local is about equal to that in Ensign, but both the president and the executive board are relatively pow- as an "autocrat") and with a relatively strong executive board (described as part of a "tight political machine"), is significantly higher than Ensign and Walker in membership participation.

It would seem that the total amount of control as well as the distribution of control may be related in important ways to participation. Control reflects an active interest on the part of the controllers in the affairs of the local. Furthermore, control itself, if properly oriented, may be instrumental in mobilizing participation and conformity to union norms. In both National and Sergeant, the members are subject to greater pressures toward participation than are the members in either Ensign or Walker. If a

TABLE 1

RANK ORDER OF LOCALS ON PARTICIPATION AND CONTROL

\begin{tabular}{|c|c|c|c|}
\hline & $\begin{array}{c}\text { MEMBERSHIP } \\
\text { PARTICI- } \\
\text { PATION }\end{array}$ & $\begin{array}{c}\text { Democratic } \\
\text { Control }\end{array}$ & $\begin{array}{c}\text { Total } \\
\text { Control }\end{array}$ \\
\hline National.. . & 1 & 1 & 2 \\
\hline Sergeant. .... & 2 & 3 & 1 \\
\hline Ensign . . . . . . & 3 & 2 & 3 \\
\hline Walker. . . . . . . & 4 & 4 & 4 \\
\hline
\end{tabular}

$\begin{array}{ccc} & \text { Officer Control } \\ \text { Executive } & \text { Bargaining } \\ \text { President } & \text { Board } & \text { Committee } \\ 4 & 2 & 3 \\ 1 & 1 & 2 \\ 3 & 4 & 1 \\ 2 & 3 & 4\end{array}$

erful there. Walker is ranked fourth, with a practically flat curve, and the members are the least powerful among the four locals. In terms of their total amount of control, the locals are ranked as follows: Sergeant, $\mathrm{Na}$ tional, Ensign, and Walker. This index, reflecting the average height of curve, was obtained by simply adding the amount of control exercised by the four levels in each local.

Considering these rankings and the level of membership participation in the four locals, two facts become evident. Participation and democratic control, though not synonymous, appear to be correlated. $\mathrm{Na}$ tional, the most democratic local, is characterized by the highest level of participation, while in Walker, the least democratic local, it is correspondingly low. Although this relationship seems obvious, another fact emerges which is perhaps of greater interest. Strong leadership control, per se, does not appear to be inimical to membership participation. Sergeant, with a powerful president (described by one international officer member fails to attend a meeting, vote in a union election, or help out during a strike, he is more likely to hear about it in these relatively active locals. However, in Sergeant such pressures are more likely to originate with the leaders, while in National it is with the members themselves. In either event, whether administered by leaders or members, sanctions for failure to participate constitute a significant force in the direction of membership activity. The relationship of control to participation is illustrated by the relative rankings of the four locals in Table 1.

\section{CONTROL AND IDEOLOGY}

Two hypotheses relating control to the goals or ideology of the union were suggested previously: (1) the greater the members' interest in broad and general social goals, the more democratic the union; and (2) the greater the members' interest in narrow and specific ("bread-and-butter") goals, the less democratic the union.

A number of questions were asked to de- 
termine the extent of member support for union goals of a relatively general social nature and those of a relatively narrow, breadand-butter type. The former include a desire for the union to "work to improve the general welfare of all the people in the community," "increase its political action," and "support the international and other unions in organizing workers." The latter include a desire for the union to "try to get higher wages for the workers," "try to get better working conditions in the shop," and "work for better health, pension, and insurance benefits." In addition, two questions were asked concerning the extent to which the international union should spend time and money organizing non-union places and get- pear in order. A general social orientation or ideology will be associated with strong internal democracy in a local union, provided that (1) the ideology itself is not undemocratic (an ideology, however broad and general, however socially or politically oriented, will not be associated with democratic procedures if it emphasizes autocratic ideals); and (2) the ideology is not held as an absolute desideratum (absolute adherence to a set of ideals may be the basis for justifying undemocratic means; these ideals may conceivably become so important as to override all other considerations-including the maintenance of democratic procedures).$^{10}$

Generally, however, if the ideology expresses a broad social responsibility and a

TABLE 2

RANK ORDER OF LOCALS AS TO SUPPORT BY MEMBERS OF BROAD AND GENERAL GoALS, AND LEVEL OF DEMOCRATIC CONTROL

\begin{tabular}{|c|c|c|c|c|c|c|}
\hline & $\begin{array}{c}\text { Democratic } \\
\text { Control }\end{array}$ & $\begin{array}{c}\text { Union Should } \\
\text { Work To } \\
\text { Improve } \\
\text { Welfare of } \\
\text { Community }\end{array}$ & $\begin{array}{l}\text { Union } \\
\text { Should } \\
\text { Increase } \\
\text { Political } \\
\text { Action }\end{array}$ & $\begin{array}{l}\text { Union Should } \\
\text { Support } \\
\text { International } \\
\text { in Unioniz- } \\
\text { ing }\end{array}$ & $\begin{array}{l}\text { International } \\
\text { Should Spend } \\
\text { Money Union- } \\
\text { izing Non- } \\
\text { union Places }\end{array}$ & $\begin{array}{l}\text { Summary } \\
\text { Rank for } \\
\text { All Broad } \\
\text { and General } \\
\text { Items }\end{array}$ \\
\hline National..... & 1 & 1 & 1 & 1 & 1 & 1 \\
\hline Ensign. . . . & 2 & 2 & 4 & 3 & 3 & 3 \\
\hline Sergeant... . & 3 & 3 & 3 & 2 & 2 & 2 \\
\hline Walker... & 4 & 4 & 2 & 4 & 4 & 4 \\
\hline
\end{tabular}

ting things for people already in the union. The former is included among the items representing an interest in relatively broad issues. The latter is treated with the breadand-butter issues. Table 2 presents the rank order of the four locals as to democratic control and as to each of the items used to measure member support for "broad and general" goals.

National ranks first on all items, and, with one exception, Walker ranks fourth. The summary rank order appears to be correlated (though imperfectly) with the level of democratic control, thus lending tentative support to the hypothesis that democratic control will be related to member interest in broad social goals. It is of further interest to note that support for broad union goals corresponds perfectly in these locals with the level of membership participation. Although these data provide some support for the hypothesis as stated, two qualifications ap- general interest in the welfare of the larger society, it is very likely to exert an influence in the direction of increased membership control within the local. Such an ideological orientation may be particularly important for the officers. A philosophy or ideology may be necessary to sustain them, to enable them to sacrifice immediate goals for longrange ideals, to resist materialistic temptations, and to think in terms of altruistic purposes. Lack of social ideology on the part of persons in power may make them especially vulnerable to appeals to personal interests, to possible racketeering and corruption.

In contrast to the foregoing data, no relationship is evident between members' orientation toward immediate and specific goals

${ }^{10}$ See Merton's discussion of aberrant behavior as a function of overemphasis uopn specific goals without a corresponding emphasis on institutional means (Robert K. Merton, Social Theory and Social Structure [Glencoe, Ill.: Free Press, 1949], chap. iv). 
for the union and democratic (or autocratic) control. Sergeant ranks first on a summary measure of these specific issues, while both Walker and National rank next. Ensign is last. These data suggest that while members of more democratic locals may tend to have a somewhat greater interest in broad and general union goals, they need not be less interested in bread-and-butter issues.

\section{UNION-MANAGEMENT CONFLICT} AND CONTROL

In addition to the ideology of the union, the extent of aggressive, union-management conflict is often considered a correlate of democratic control within the union. While we do not have a measure in the questionnaire of the unions' actual militancy toward management, personal observations of the four locals have been sufficiently intensive to permit a clear ranking of them in the following order: Sergeant, National, Ensign, and Walker. This ordering, however, does not correspond with the index of democratic control and does not support the original hypothesis. There is little indication in these data that militancy on the part of the union is related to the practice in that union of democratic control. However, another hypothesis is suggested: that connecting unionmanagement conflict to the total amount of control exercised within the local. This relationship appears explicable in terms of two contrasting and perhaps contravening implications of union-management conflict. On the one hand, we have the suggestion that "continued ... antagonism between corporations and unions prevents the latter from sinking into bureaucratic sloth. Merely to survive, the union must remain vital, democratic and militant."'ll Conflict will often activate an otherwise apathetic membership. On the other hand, conflict between social groups frequently leads to the restriction and not the expansion of internal freedom. In some instances the fact of external conflict is more rationalization than cause, and the abandonment of democratic proce-

${ }^{11}$ Howe and Widick, op. cit., p. 259. dures within an organization undergoing conflict may be justified "as a desperate measure to unify the union in time of economic distress and organizational disorder." ${ }^{\prime 2}$ Nor is it completely unlikely that conflict may be manufactured by leaders as a means of consolidating power within an organization. Democratic control is sometimes seen as "inefficient" and as impeding the effectiveness of an organization in crisis, while control by the leaders is often explained as an expedient necessary to pull the union through periods of conflict and difficulty:

It is a question of whether you desire your organization to be the most effective instrumentality ... or whether you prefer to sacrifice the efficiency of your organization in some respect for a little more academic freedom in the selection of some local representa tive. ... What do you want? Do you want an efficient organization or do you want merely a political instrumentality?13

Conformity within the union is considered a requirement of success in its struggle with management. The truth of this assertion might be questioned, but it is nevertheless believed by many; an international president observed: "... democracy does not come cheap: the price is a certain amount of confusion and disunity."14 But "confusion and disunity" cannot always be tolerated during times of strife, and conflict with an outside enemy often has the effect of banishing them. Lines are drawn, a common purpose is accepted, and control is very likely to be increased. An organization under these conditions must be more highly regulated in order to survive. Common acceptance of this notion increases the amenability of members to the regulations of the organization.

However, viewing the issue in terms of the control graphs suggests that increased

12 James A. Wechsler, Labor Baron: A Portrait of John L. Lewis (New York: William Morrow \& Co., 1944), p. 80.

${ }^{13}$ John L. Lewis, quoted ibid., p. 79.

${ }^{14}$ Paul L. Phillips, "Unions and Politics, Anglo American Contrasts," Nation, CLXXIX (October 30, 1954), 382-84. 
control need not be autocratic any more than it need be democratic. Interorganizational conflict may serve as an incentive for concentrating control in the hands of a few or for increasing the total amount of control in the organization in other ways. The important thing is that the organization be more tightly controlled. We are therefore led to the hypothesis that interorganizational strife will create an increase in total control -but not necessarily exerted at the top or at the bottom of the organization. The increased control may come primarily from the rank and file, it may come relatively more from the officers, or it may come from both. The distribution of this increased control is determined by other factors, among led, however, to the further view that control in a union is part of a larger syndrome. A high level of control within the local and militant conflict with management is part of an organizational pattern characteristic of many strong and vital labor unions. Among the correlates of this syndrome we would expect the following variables: organizational power, total control, inter- and intra-organizational conflict, participation, loyalty, and conformity (see Table 3). The connections among these variables, of course, are not rigid and inexorable, but we would predict their association as a pattern. Furthermore, the effects of these variables may be reciprocal in some cases. This becomes evident when we consider further the

TABLE 3

RANK ORDER OF LOCALS ON VARIABLES IN ORganizational POWER SyNDROME

$\begin{array}{lccccccc} & \begin{array}{c}\text { Union } \\ \text { Power }\end{array} & \begin{array}{c}\text { Total } \\ \text { Control }\end{array} & \begin{array}{c}\text { Union- } \\ \text { Management } \\ \text { Conflict }\end{array} & \begin{array}{c}\text { Intra- } \\ \text { local } \\ \text { Conflict }\end{array} & \text { Loyalty } & \text { Conformity } & \begin{array}{c}\text { Partici- } \\ \text { pation }\end{array} \\ \text { Sergeant...... } & 1 & 1 & 1 & 1 & 1 & 1 & 2 \\ \text { National..... } & 2 & 2 & 2 & 2 & 2 & 2 & 1 \\ \text { Ensign. .... } & 3 & 3 & 3 & 4 & 3 & 3 & 3 \\ \text { Walker. ..... } & 4 & 4 & 4 & 3 & 4 & 4 & 4\end{array}$

them, perhaps, the ideological orientation of the participants. We are suggesting, therefore, that while conflict may have a bearing on the shape of the control curve, its most predictable effect will be on the average height of this curve: conflict may be associated with a high degree of control either by members or by leaders, but it will almost invariably be associa ted with an increase in total control. The data of the present study, which reveal a direct correspondence between the extent of aggressiveness toward management and total control, provide support for this notion.

\section{THE ORGANIZATIONAL POWER SYNDROME}

The data discussed here have given tentative support to the hypotheses that the level of democratic control in a local is related to the members' interest in broad and general goals for the union and that the total amount of control is related to the extent of union-management conflict. We are union in conflict with its management. The union's success in achieving its goals is often contingent on its power-its ability to impose, or threaten the imposition of, sanctions. This power in turn depends partly on concerted member action and member readiness to "stand behind" their organization in the face of adversity, on conformity to union norms and loyalty to its goals. The increased control created by conflict is an adjustment, instrumental to mobilization. It becomes directed partly toward co-ordinating member action and partly toward the internal administration of sanctions for breaches in union policy. It is an internal mechanism designed in part to bolster external power.

This increased control serves other functions for unions engaging in conflict with management: in a very real sense, there is more to be controlled during such periods. The repertory of union actions increases, committees become activated, decisions must be 
made concerning the dispensation of benefits anticipated or achieved from management. All this stimulates the interest and participation of the members - and they, too, may have to be controlled. Union policy becomes a day-to-day affair, changing with the tide of battle. New issues arise which require regulation; and, although the leaders are not likely to relinquish power during such periods, the members may increase theirs. They now want a say on issues which are of vital importance to them.

The loyalty of members is associated with this syndrome in a number of ways. Conflict creates, or at least arouses, the members' loyalty ${ }^{15}$ During times of conflict, danger to the union is more imminent and awareness of the union's importance to the members more apparent. Furthermore, a union "carrying on aggressive struggles" may be demonstrating its value to the members: it is attempting to derive benefits for them, and its success in this endeavor is likely to be a cause for satisfaction and loyalty. Thus the results of organizational power return ultimately to enhance this power. The adage that "nothing succeeds like success" is especially apparent in unions. To this extent, power can become its own mainstay.

Intra-organizational conflict is also expected as part of this syndrome..$^{16}$ The fact that there is greater involvement and activity and a correspondingly greater interest in control of the organization is likely to lead to some element of conflict within the local through which different interests and points of view are reconciled. In the extreme case of the "power centers," for example, "internal political rivalries between factional machines are likely to be intense because

${ }^{15}$ See, e.g., William Becker, "Conflict as a Source of Solidarity," Journal of Social Issues, IX, No. 1 (1953), 25-27.

${ }^{16}$ Although factionalization or intra-organizational conflict may imply special subgroup loyalties within the union, these need not contravene the loyalty of the members to the union itself. On the contrary, such intra-union affiliations may serve to arouse greater loyalty among the participants to the larger organization. Lipset has observed this phenomenon in the ITU (personal communication). the stakes in the struggle over power are so large."17 Furthermore, this internal conflict may contribute to the intensity of the conflict between the union and its management. Under these circumstances "each side may be committed before the bargaining starts to programs which stem from protracted discussions and expedient compromises of conflicting viewpoints within its own group. There is usually an absence of flexibility, therefore, in the joint union-management decision making process. This fact makes agreement much more difficult." 18

Finally, we might consider the relation of member conformity to some of the other elements of the syndrome. The existence of conformity is contingent upon the (formal and informal) definitions of rules and policies around which uniformity is to take place. Control implies the formulation of such rules (legislative control) and the regulation of behavior in accord with these rules (administrative and sanctions control). ${ }^{19}$ The possible receipt of criticism or punishment for failure to adhere to the rules of an organization is an effective force toward uniformity. A high level of total control, therefore, leads to a greater degree of order and uniformity in an organization. Control creates conformity. Second, external conflict develops an ostensible need for unity. Members are willing to sacrifice and conform in a crisis who otherwise might be less subject to the influence of the union. Conflict justifies uniformity. Third, loyalty motivates the member to support the rules, standards, and policies of the organization. The loyal member wants to adhere to organizational norms. He wants to do what is "right" for the organization. Loyalty fortifies uniformity. Finally, participation has a bearing on conformity. It is through participation that the

${ }^{17}$ F. H. Harbison and R. Dubin, Patterns of Union Management Relations (New York: Science Research Associates, 1947), pp. 185-86.

${ }^{18}$ Ibid., p. 186.

${ }^{19}$ Nancy C. Morse, Everett Reimer, and Arnold S. Tannenbaum, "Regulation and Control in Hierarchical Organizations," Journal of Social Issues, VII, No. 3 (1951), 41-48. 
member comes into contact with organizational norms, sees what is "right" and what is "wrong," and learns what is required of him. He himself may also help set the norms. Participation thus expedites uniformity.

In the preceding material are outlined briefly some of the interconnections among the variables in the organizational power syndrome. The dimension of total control is one aspect of this larger pattern. Table 3 presents the rank order of the four locals on each of the items discussed. Measures are available in the questionnaire for each, exclusive of union-management conflict and organizational power. ${ }^{20}$ For measures of these, reliance is placed on personal observations of the locals, in addition to general

${ }^{20}$ Intra-organizational conflict was measured through an index of three questions: "Do these [groups within the local] disagree on most matters or only a few?" "Do these groups have leaders who speak up for them?" "When these groups disagree, how much do you find yourself taking sides?"

Loyalty, similarly, was measured by three items: "Suppose the union went through a strike which so weakened it that it was in real danger of folding up. How much would you be willing to do about it?" "Suppose that there was so much disagreement within the local that it was in real danger of folding up. How much would you be willing to do about it? "If the local went out on strike, how willing would you be to do picket duty?"

Uniformity of behavior within the local was measured as the inverse of variance on a number of items chosen a priori to reflect union norms. These items include perceived norms about voting, attending meetings, and helping out on strikes; the likelihood of sanctions against members for failure to perform these functions; the intensity of member involvement in the union; and the alacrity with which members utilize union channels for the expression of grievances.

A more detailed discussion of these measures is to appear in a forthcoming book by A. S. Tannenbaum and R. L. Kahn. comments of international and company officials as well as comments of members. For example, Sergeant, which is ranked first in power, is widely recognized as "carrying a hell of a lot of weight," as one regional director of another international described it. The personnel manager at the Sergeant plant also recognized its power and militancy when he pointed out, philosophically, that the union "keeps management on its toes."

In contrast, the weakness of Walker, the least powerful among the four locals, is evident to all who know it; a field representative commented: "If the company wanted to take advantage, they could make the people live hard here." An old-timer expressed his disillusionment with the effectiveness of this local: "We feel that it's not what it used to be. ... Nothing happens to grievances. You can't find out what happens to them - they get lost.... The [bargaining] committee doesn't fight any more."

\section{SUMMARY}

The control graph illustrates the importance of two distinct aspects of control in organizations: the distribution of control and the total amount of control. Variations on these dimensions are hypothesized to relate to other aspects of union functioning, including membership participation, the expressed ideology of the members, and conflict with management. A broader syndrome of variables is suggested, including a number of determinants and implications of control. These include union power, intra- as well as interorganizational conflict, membership loyalty, participation, and conformity.

UNIVERSITY OF MICHIGAN 